\title{
ANTIBACTERIAL EFFECT OF JAVA TURMERIC ETHANOL EXTRACT AGAINST DUAL-SPECIES STREPTOCOCCUS MUTANS AND STREPTOCOCCUS SANGUINIS BIOFILM (IN VITRO)
}

\author{
AJRINA BUSRI, RIA PUSPITAWATI*, SRI UTAMI
}

Department of Oral Biology, Faculty of Dentistry, Universitas Indonesia, Jakarta, Indonesia. Email: rpuspitawati2013@gmail.com

Received: 21 April 2017, Revised and Accepted: 13 July 2017

\section{ABSTRACT}

Objectives: The minimal bactericidal concentration (MBC) of Java turmeric (Curcuma xanthorrhiza Roxb.) ethanol extract is $25 \%$ against Streptococcus mutans and 15\% against Streptococcus sanguinis as single species. This study aimed to examine the antibacterial effect of Java turmeric ethanol extract against S. mutans and S. sanguinis as dual-species. S. mutans and S. sanguinis compete against each other to obtain nutrients.

Methods: The antibacterial effect of Java turmeric ethanol extract against dual-species Streptococcus in vitro was analyzed by measuring the growth of bacteria after exposure to the extract by counting colony formation and quantifying bacterial cell numbers using real-time polymerase chain reaction.

Result: The MBC of Java turmeric ethanol extract against dual-species Streptococcus is $10 \%$. S. sanguinis is more sensitive to the extract than S. mutans.

Conclusions: The antibacterial effect of Java turmeric ethanol extract on S. mutans and S. sanguinis as single species differs from the effect on the bacteria as dual-species of Streptococcus.

Keywords: Dual-species Streptococcus, Java turmeric ethanol extract, Streptococcus mutans, Streptococcus sanguinis

(C) 2017 The Authors. Published by Innovare Academic Sciences Pvt Ltd. This is an open access article under the CC BY license (http://creativecommons. org/licenses/by/4. 0/) DOI: http://dx.doi.org/10.22159/ajpcr.2017.v10s5.23096

\section{INTRODUCTION}

Dental caries is a hard tissue disease in teeth caused by the gradual chronic loss of mineral ions from enamel, dentin, and cementum [1]. Dental caries is one of the most frequently seen oral infections in society, regardless of age group and economic status. The United States surgeon general has reported that $45 \%$ of children between 5 and 17 years old suffer from dental caries [2]. The prevalence of dental caries in different countries is relatively high, especially in Indonesia. According to the Basic Health Survey 2013, 72.3\% Indonesian population was suffering from caries experience [3].

Caries can form as a result of the interaction of a number of factors, including host (tooth structure and saliva), bacteria (cariogenic bacteria, especially Streptococcus and Lactobacilli sp.), substrate (fermented food), and time [1]. The formation of dental caries begins with the formation of pellicle. Pellicle is a thin layer of the matrix on the tooth surface, which is formed by saliva. The pellicle is colonized by Streptococcus sanguinis, which is an early colonizing bacterium [4]. $S$. sanguinis coaggregate with other bacteria, such as Streptococcus mutans, to form dental plaque or dental biofilm. Dental biofilm is a soft layer composed of microorganisms cultivating on pellicle and is attached to tooth surfaces [5]. Dental biofilm is normally always present on the tooth surfaces [6]. Biofilm can be composed of many different interacting species [7]. The accumulated different species of bacteria interact in a mechanism called quorum sensing, causing changes in the composition of microbes, which then leads to the formation of caries [6].

Previous studies by Caufield et al. (2002) stated that S. sanguinis interacts by opposing $S$. mutans to colonize the tooth surface. Both bacteria need tooth surface for colonization. The interaction between $S$. sanguinis and $S$. mutans is affected by environmental factors, such as the density of the colony, the availability of nutrition, and $\mathrm{pH}$ [8]. Studies by Kreth et al. showed that the interaction between $S$. mutans and $S$. sanguinis was influenced by conditions in the environment. $S$. mutans and $S$. sanguinis produce substances that are able to suppress the growth of other species. $S$. mutans produces mutacin, which has the ability to suppress the growth of $S$. sanguinis. On the contrary, $S$. sanguinis produces hydrogen peroxide, which can suppress the growth of $S$. mutans [9].

Maintaining good oral hygiene contributes to preventing the formation of dental caries. There are many different methods to maintain good oral hygiene; among them are mechanical cleansing and the use of chemical agents. The mechanical method involves the use of a toothbrush to eliminate dental biofilm, whereas the chemical method involves using mouthwash as an antimicrobial agent [10]. Mouthwash has the ability to kill bacteria [11]. However, prolonged use of mouthwash may cause tooth discoloration. Besides that, mouthwash that contains alcohol may cause xerostomia and irritation of the mucosa. Thus, the development of alternative agents of caries prevention that are relatively cheap and safe is needed [11].

Currently, traditional medicine is used as an alternative in the prevention and as a cure for diseases, it is relatively cheap and safe. Traditional medicine is a mixture of substances, derived from plants, animals, minerals, or a mixture of these, that have been passed down from generation to generation and have been used as medicine based on experience. Indonesian traditional medicines are divided into herbal medicine (in Indonesia known as jamu), standardized herbal medicine, and fitofarmaka, a form of herbal medicine that has been clinically tested. Jamu is the traditional medicine that has not been subjected to any kind of scientific testing but has been passed down through generations. Standardized herbal medicine has been scientifically tested for its safety and benefits. Fitofarmaka is the natural herbal medicine that has been scientifically proven for its safety and benefits, has undergone preclinical and clinical testing, and has standardized raw materials and products [12].

Indonesia is known as a country with biodiversity and has an abundant agricultural production. There has been an increase in agricultural production, especially in the development of herbal medicine. According to the World Health Organization, there are 20,000 types 
of plants in the world that can be used for medicine, and more than 2,200 types of plants are present in Indonesia [13]. Badan Pengawas Obat dan Makanan (the Board of Drugs and Food Supervision) of the Health Department in Indonesia has determined nine leading herbal medicines in Indonesia, including Curcuma xanthorrhiza Roxb. or Java turmeric (known in Indonesia as temulawak) [14].

Java turmeric is a member of the Zingiberaceae family and is native to Indonesia. Its establishment as a leading herbal medicine is based on it benefits [13]. It contains a yellow substance (curcumin), starch, protein, fat (fixed oil), cellulose, minerals, and essential oil. Curcumin is used as a food supplement to increase appetite and has anti-inflammatory and antioxidant potentials. The contents of the starch, protein, fat (fixed oil), cellulose, and minerals in Java turmeric can act as a substitute for food. The contents of the essential oil in Java turmeric include active substances such as xanthorrhizol.

Hwang et al. (1999) conducted a study using xanthorrhizol isolated from Java turmeric. The research proved that xanthorrhizol had anticaries activities for fighting oral pathogens, especially $S$. mutans. Xanthorrhizol can kill S. mutans and shows activities as an antibacterial agent that can prevent the formation of S. mutans biofilm.

Based on the research at the Oral Biology Laboratory, Faculty of Dentistry, Universitas Indonesia, it is known that the minimum inhibitory concentration (MIC) of Java turmeric ethanol extract against $S$. mutans is $0.5 \%(5 \mathrm{mg} / \mathrm{mL})$, and the minimum bactericidal concentration (MBC) is $25 \%(250 \mathrm{mg} / \mathrm{mL})$. However, Java turmeric ethanol extract has an MIC of $0.5 \%(5 \mathrm{mg} / \mathrm{mL})$ and an MBC of $15 \%(150 \mathrm{mg} / \mathrm{mL})$ against S. sanguins. Based on previous studies, the effective concentration of ethanol extract varies in different species of bacteria.

\section{METHODS}

This study was a laboratory experimental study using the bacteria S. mutans ATCC 25175 and S. sanguinis ATCC 10556 obtained from the Oral Biology Laboratory of the Faculty of Dentistry, Universitas Indonesia. Before exposure to the extract, the concentrations of the bacteria with dilutions and inoculations on agar were determined. A concentration of $10^{5} \mathrm{ml}$ was chosen for both $S$. mutans and S. sanguinis. The control group was divided into two main group: Negative control, which are bacteria without any treatment; and a positive control, which are bacteria exposed to chlorhexidine. The dual-species bacteria were obtained by mixing S. mutans and S. sanguinis in equal concentrations (1:1).

Java turmeric ethanol extract was obtained by a maceration process in Research Center for Spice and Drugs Plant (BALLITRO) and was diluted into different concentrations using dimethyl sulfoxide $10 \%$. The resulting ethanol extract was used in concentrations of $0.2 \%, 1 \%, 5 \%$, $10 \%$, and $15 \%$.

The bacterial suspension was mixed with Java turmeric ethanol extract and inoculated on an agar medium. Bacteria that had been exposed to the extract were put in an anaerobic jar filled with $\mathrm{N}_{2}$ gas balance, $10 \%$ $\mathrm{CO}_{2}$, and $10 \% \mathrm{H}_{2}$, and incubated in an incubator at $37^{\circ} \mathrm{C}$ for $48 \mathrm{hrs}$.

Quantification of S. mutans and S. sanguinis in the dual-species biofilm before and after exposure to Java turmeric ethanol extract was done. Sterile saliva was put into a 24 -well plate and incubated at $37^{\circ} \mathrm{C}$ for 60 minutes to form pellicle and also biofilm by adding bacteria. The biofilm was divided into two groups: Single species (control) and dual species (with and without exposure to Java turmeric ethanol extract). The biofilm sample was incubated at $37^{\circ} \mathrm{C}$ for $24 \mathrm{hrs}$. The bacterial DNA in the biofilm was extracted using a thermal shock. The concentration and purity of the DNA sample were then evaluated. Bacterial DNA was then quantified using real-time polymerase chain reaction (PCR).

The data obtained from the antibacterial test of Java turmeric ethanol extract was then analyzed with the Shapiro-Wilk test for normality. The data on the total number of colonies were not normally distributed and were tested with non-parametric tests: Kruskal-Wallis and MannWhitney tests, to determine whether there was a significant difference between the two variables. However, the quantification results were relatively normally distributed and were further tested with an unpaired t-test. The statistical test performed had a significance of 0.05 $(p=0.05)$ and a reliability of $95 \%(\alpha=0.05)$

\section{RESULTS}

The results of the experiments on the number of colonies formed after exposure to Java turmeric ethanol extract are presented on Figs. 1-3.

The statistical test used was a Kruskal-Wallis test, and the results showed that there was a significant difference between the number of colonies of bacteria in every treatment group. In the Mann-Whitney test, there was a significant difference between the negative control group and the groups treated with Java turmeric ethanol extract. There was a significant difference between the positive control group and the singlespecies Streptococcus groups treated with Java turmeric ethanol extract at concentrations of $0.2 \%, 1 \%, 5 \%$, and $10 \%$, and the dual-species Streptococcus group treated with $0.2 \%, 1 \%$, and $5 \%$ concentrations. There was no significant difference between the positive control group and the single-species Streptococcus groups treated with Java turmeric ethanol extract at a concentration of $15 \%$, and the dual-species Streptococcus group treated with $10 \%$ Java turmeric ethanol extract.

The results of the quantification using real-time PCR with a relative count of $2^{-\Delta \Delta t}$ is shown in Fig. 4 . The relative quantification is done to obtain values for gene expression from the target. Gene expression represents the number of bacteria used in a sample. The relative count

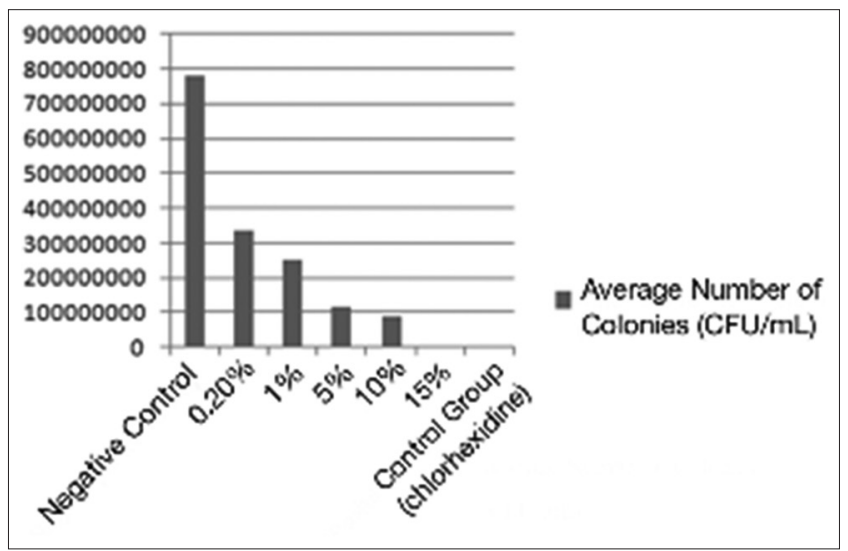

Fig. 1: The average number of colonies of Streptococcus mutans (CFU/mL) after exposure to Java turmeric ethanol extract

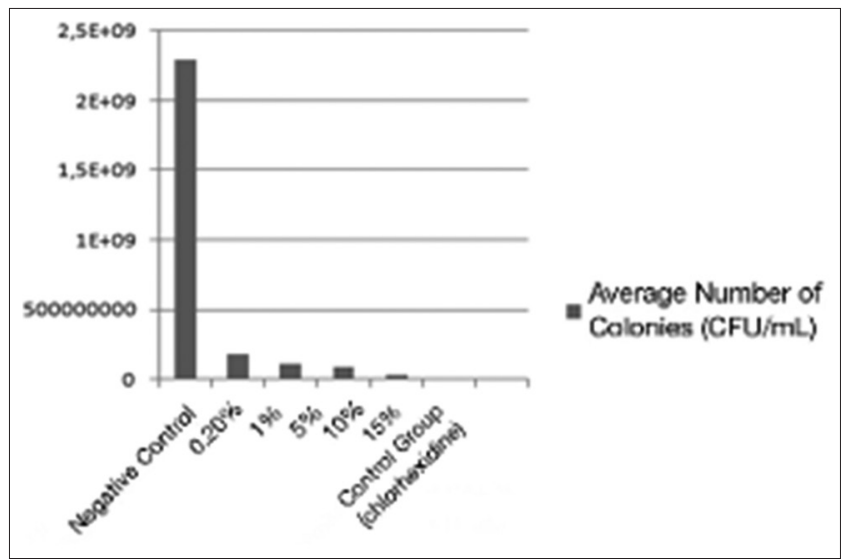

Fig. 2: The average number of colonies of Streptococcus sanguinis (CFU/mL) after exposure to Java turmeric ethanol extract 
produces a bacterial expression ratio between the groups studied and the control groups. The control groups are single-species Streptococcus bacteria. After that a statistical test was conducted using an unpaired t-test to evaluate the significant difference between two unrelated groups. There were different quantities of $S$. mutans and S. sanguinis in the biofilm of dual-species Streptococcus without exposure to Java turmeric ethanol extract, but the difference was not significant. After exposure to Java turmeric ethanol extract, the difference in the quantities of $S$. mutans and $S$. sanguinis in the biofilm of dual species Streptococcus was significant.

\section{DISCUSSION}

After exposure to Java turmeric ethanol extract, the bacteria were incubated for $48 \mathrm{hrs}$, which is the optimal time for S. mutans and $S$. sanguinis growth. Antibacterials are more effective during the division of bacteria when cell walls containing phospholipids become thinner, enabling antibacterials to penetrate, and cause lysis [15].

An increase in the concentration of Java turmeric ethanol extract causes a reduction in the number of colonies of $S$. mutans and S. sanguinis. The results of this research show that the MIC of Java turmeric ethanol extract to $S$. mutans and S. sanguinis as single and dual species was $0.2 \%$. The MBC of Java turmeric ethanol extract to $S$. mutans and S. sanguinis as single species was $15 \%$ but was $10 \%$ for dual-species Streptococcus. These results show that the antibacterial effect of Java turmeric ethanol extract on dual-species Streptococcus is lower than its effect on single species of Streptococcus. This may be due to the competition between S. mutans and S. sanguinis. The competition between $S$. mutans and S. sanguinis is affected by their environment. In an environment with limited nutrition, $S$. mutans and $S$. sanguinis produce substances that can inhibit the growth of other species. Streptococcus mutans produce mutacin to inhibit the growth of S. sanguinis. Meanwhile, S. sanguinis produce hydrogen peroxide, which is able to inhibit the growth of S. mutans. In this study, the dual-species Streptococcus was in an environment of limited nutrition because sucrose was not added to its medium. Based on the results of the colony count of single species compared with the negative control group, Java turmeric ethanol extract causes a greater reduction in the number of S. sanguinis (98\%), compared to S. mutans (52\%). It can be assumed that $S$. sanguinis is more sensitive to Java turmeric ethanol extract, whereas $S$. mutans is more resistant. This may be because $S$. mutans produces a dextran capsule that encapsulates its cell walls, making it stronger and more resistant to antibacterial penetration.

Java turmeric ethanol extract contains starch, curcuminoid, and essential oils. Essential oils contain active substances such as xanthorrhizol. Xanthorrhizol contains phenol and hydrocarbol compounds. Phenol compounds consist of different compounds derived from plants of the same characteristics, having an aromatic ring and containing one or more hydroxyl groups $(-\mathrm{OH})$. This compound interacts with bacterial cells through adsorption involving a hydrogen bond. At high concentrations, xanthorrhizol coagulates with cellular protein and cytoplasmic membranes and undergoes lysis. However, at low concentrations, xanthorrhizol will bond with cellular proteins and form a phenol complex protein with weak bonds and will dissociate. Phenol damages the cytoplasmic membrane and causes leakage of the cell wall, eventually causing cell death.

Fig. 4 indicates an increase in the growth of $S$. mutans and the inhibition of $S$. sanguinis in dual-species Streptococcus. This shows that in a dualspecies environment, $S$. mutans competes against $S$. sanguinis without antibacterial intervention. Streptococcus mutans is more dominant and is able to inhibit the growth of $S$. sanguinis. In dual-species Streptococcus exposed to Java turmeric ethanol extract, $S$. mutans can be seen as being more dominant $(\mathrm{p}<0.05)$. This is due to the sensitivity of $S$. sanguinis to Java turmeric extract and competition against $S$. mutans.

Further studies are recommended to examine the efficacy of Java turmeric ethanol extract toward other cariogenic Streptococcus

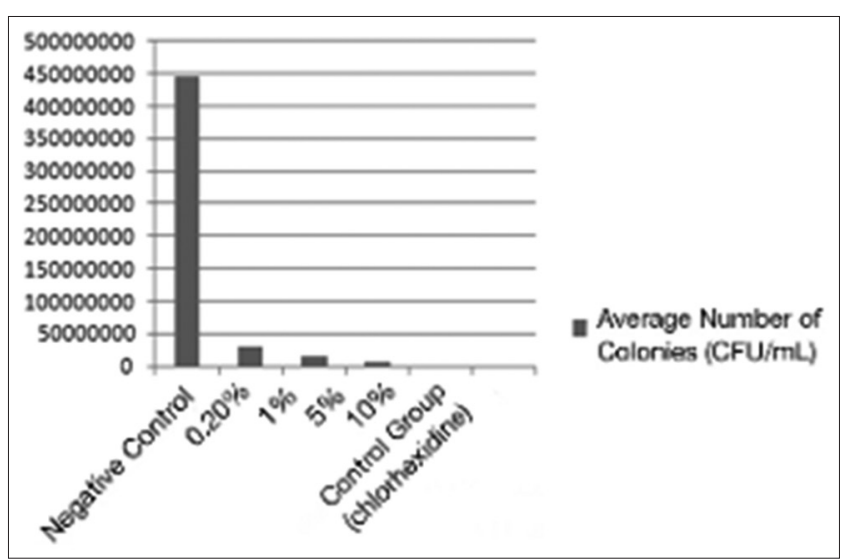

Fig. 3: The average number of colonies of dual-species Streptococcus $(\mathrm{CFU} / \mathrm{mL})$ after exposure to Java turmeric ethanol extract

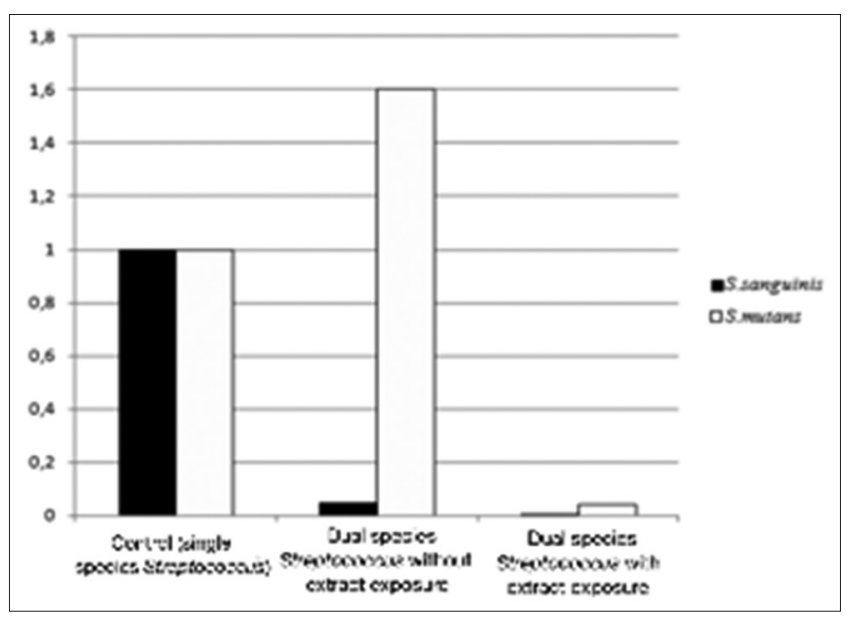

Fig. 4: The relative average of Streptococcus mutans and Streptococcus sanguinis with and without Java turmeric extract exposure on dual-species Streptococcus with real-time polymerase chain reaction

bacteria, and also the effect of Java turmeric extract on the virulence of those cariogenic bacteria.

\section{CONCLUSION}

Based on this research, it can be concluded that the antibacterial effect of Java turmeric ethanol extract toward S. mutans and S. sanguinis as single species is different compared to its effect on them as a dualspecies Streptococcus. Exposure of dual-species Streptococcus biofilm to $15 \%$ Java turmeric ethanol extract caused a greater decrease in the growth of $S$. sanguinis compared to $S$. mutans. This shows that $S$. sanguinis has greater sensitivity to Java turmeric ethanol extract than S. mutans.

\section{REFERENCES}

1. Mount GJ, Hume WR. Preservation and Restoration of Tooth Structures. $2^{\text {nd }}$ ed. Queensland: Rob Watts; 2005.

2. Allukian M Jr. The neglected epidemic and the surgeon general's report: A call to action for better oral health. Am J Public Health 2000;90(6):843-5.

3. Indonesian Ministry of Health. Basic Health Survey. Jakarta: Indonesian Ministry of Health; 2013.

4. Shay K. Infectious complications of dental and periodontal diseases in the elderly population. Clin Infect Dis 2002;34(9):1215-3.

5. Pintauli S, Hamada T. Menuju Gigi Dan Mulut Sehat: Pencegahan Dan Pemeliharaan. Medan: USU Press; 2008. 
6. Marsh P, Martin MV. Oral Microbiology. $4^{\text {th }}$ ed. Oxford: Wright; 1999

7. Burmølle M, Webb JS, Rao D, Hansen LH, Sørensen SJ, Kjelleberg S. Enhanced biofilm formation and increased resistance to antimicrobial agents and bacterial invasion are caused by synergistic interactions in multispecies biofilms. Appl Environ Microbiol 2006;72:3916-23.

8. Li YH, Tian X. Quorum sensing and bacterial social interactions in biofilms. Sensors (Basel) 2012;12(6):2519-38.

9. Kreth J, Merritt J, Shi W, Qi F. Competition and coexistence between Streptococcus mutans and Streptococcus sanguinis in the dental biofilm. J Bacteriol 2005;187(3):7193-203.

10. Lewis DW, Ismail AI. Periodic health examination, 1995 update: 2. Prevention of dental caries. The canadian task force on the periodic health examination. CMAJ 1995;152(21):836-46.
11. Nurdeviyanti N. Iodized table salt inhibit the growth of Streptococcus mutans in vitro. Thesis. Denpasar: Universitas Udayana; 2011.

12. Indonesian Food and Drugs Administration. Kriteria dan tatalaksana pendaftaran obat tradisional. Obat Herbal Terstandar Dan Fitofarmaka. Jakarta: Indonesian FDA; 2005.

13. Pribadi ER, Raharjo M. Efisiensi pemupukan NPK pada temulawak. Littri 2008;14(4):162-70

14. Mangunwardoyo W, Deasywaty D, Usia T. Antimicrobial and identification of active compound Curcuma xanthorrhiza roxb. Int J Basic Appl Sci IJBAS-IJENS 2012;12(1):69-78.

15. Jenkins $\mathrm{S}$, Addy $\mathrm{M}$, Wade $\mathrm{W}$. The mechanism of action of chlorhexidine. A study of plaque growth on enamel inserts in vivo. J Clin Periodontol 1988;15(7):415-24. 